\title{
Anther and pollen development in some species of Poaceae (Poales)
}

\author{
Nakamura, AT. ${ }^{\mathrm{a} *}$, Longhi-Wagner, HM. ${ }^{\mathrm{b}}$ and Scatena, $V$. $^{\mathrm{c}}$

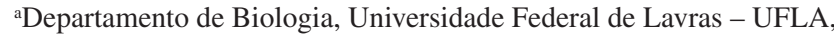 \\ Campus Universitário, CP 37, CEP 7200-000, Lavras, MG, Brazil \\ 'Departamento de Botânica, Instituto de Biociências, Universidade Federal do Rio Grande do Sul - UFRS, \\ Av. Bento Gonçalves, 9500, Prédio 43323, Agronomia, CEP 91501-970, Porto Alegre, RS, Brazil \\ 'Departamento de Botânica, Instituto de Biociências, Universidade Estadual Paulista "Júlio de Mesquita Filho" - UNESP, \\ Av. 24-A, 1515, Bela Vista, CEP 13506-900, Rio Claro, SP, Brazil \\ *e-mail: nakamura@dbi.ufla.br
}

Received August 8, 2008 - Accepted October 14, 2008 - Distributed May 31, 2010

(With 34 figures)

\begin{abstract}
Anther and pollen development were studied in Olyra humilis Nees, Sucrea monophylla Soderstr, (Bambusoideae), Axonopus aureus P. Beauv., Paspalum polyphyllum Nees ex Trin. (Panicoideae), Eragrostis solida Nees, and Chloris elata Desv. (Chloridoideae). The objective of this study was to characterise, embryologically, these species of subfamilies which are considered basal, intermediate and derivate, respectively. The species are similar to each other and to other Poaceae. They present the following characters: tetrasporangiate anthers; monocotyledonous-type anther wall development, endothecium showing annular thickenings, secretory tapetum; successive microsporogenesis; isobilateral tetrads; spheroidal, tricellular, monoporate pollen grains with annulus and operculum. Nevertheless, the exine patterns of the species studied are distinct. Olyra humilis and Sucrea monophylla (Bambusoideae) show a granulose pattern, whereas in the other species, it is insular. In addition, Axonopus aureus and Paspalum polyphyllum (Panicoideae) have a compactly insular spinule pattern, while Chloris elata and Eragrostis solida (Chloridoideae) show a sparsely insular spinule pattern. The exine ornamentation may be considered an important feature at the infrafamiliar level.
\end{abstract}

Keywords: Bambusoideae, Chloridoideae, Gramineae, microsporogenesis, Panicoideae.

\section{Desenvolvimento da antera e do grão de pólen em espécies de Poaceae (Poales)}

\section{Resumo}

O desenvolvimento da antera e do grão de pólen de Olyra humilis Nees, Sucrea monophylla Soderstr. (Bambusoideae), Axonopus aureus P. Beauv., Paspalum polyphyllum Nees ex Trin. (Panicoideae), Eragrostis solida Nees and Chloris elata Desv. (Chloridoideae) foi estudado visando caracterizar embriologicamente essas espécies de subfamílias consideradas basal, intermediária e derivada, respectivamente. As espécies são similares entre si e entre as demais Poaceae. Apresentam os seguintes caracteres: anteras tetrasporangiadas; desenvolvimento da parede da antera do tipo monocotiledôneo, endotécio com espessamento de parede anelar, tapete secretor; microsporogênese sucessiva; tétrades isobilaterais; grãos de pólen esféricos, tricelulares, monoporados, com anel e opérculo. Por outro lado, o padrão de ornamentação da exina do grão de pólen é distinto. Olyra humilis e Sucrea monophylla (Bambusoideae) apresentam padrão granuloso e as demais espécies padrão insular. Axonopus aureus e Paspalum polyphyllum (Panicoideae) apresentam espínulos densamente agrupados, enquanto Chloris elata e Eragrostis solida (Chloridoideae) espínulos esparsamente agrupados. A ornamentação da exina dos grãos de pólen pode ser considerada caráter importante a nível infrafamiliar.

Palavras-chave: Bambusoideae, Chloridoideae, Gramineae, microsporogênese, Panicoideae. 


\section{Introduction}

Understanding the embryology of the Poaceae species is of considerable interest due to the economic and ecological importance of this group. Being one of the largest Angiosperm families, Poaceae comprises 10,000 species and over 700 genera (GPWG, 2001). They are distributed in 13 subfamilies (Sánchez-Ken et al., 2007), with species occurring in all continents and all types of habitats. Poaceae is included in Poales with another 17 families (APG II, 2003), except for Hydatellaceae (Saarela et al., 2007), which accounts for approximately one third of the Monocotyledons (Linder and Rudall, 2005).

Most Poales present monocotyledonous-type anther development (Sajo et al., 2005), secretory tapetum (Furness and Rudall, 1998; 2001), and successive cytokinesis (Furness and Rudall, 2001), features which are also shared by other monocots (Furness and Rudall, 2001). In addition, Bhanwra (1988) reported the presence of only four layers of microsporangium cells in Poaceae, one of the family synapomorphies. Bhanwra (1988) also stated that male embryological traits are common in the family.

Embryological features may be useful in taxonomy as they may indicate taxon boundaries, determine affinities, and aid in the evaluation of classification schemes (Björnstad, 1970). Although phenotypic plasticity in embryological traits is small, it is suggested that the high specific richness and the broad distribution of Poaceae species may have influenced the group embryology. This would lead to a more efficient use of microsporangium and microgametophyte traits in the phylogenetic analyses of the group, as has been done for Asparagales (Rudall et al., 1997). Within this order, the simultaneous microsporogenesis was considered an apomorphic character, in addition to the rare occurrence of the anatrichotomocolpate pollen aperture in Monocotyledons.

In the present study, Bambusoideae was considered the basal subfamily, Panicoideae intermediate, and Chloridoideae derivate (GPWG, 2001). The present study aimed to characterise Olyra humilis Nees, Sucrea monophylla Soderstr. (Bambusoideae - Olyreae), Axonopus aureus P. Beauv., Paspalum polyphyllum Nees ex Trin. (Panicoideae - Paniceae) and Eragrostis solida Nees (Chloridoideae - Eragrostideae) and Chloris elata Desv. (Chloridoideae - Cynodonteae) embryologically at the subfamilial level.

\section{Materials and Methods}

Samples of Olyra humilis Nees, Sucrea monophylla Soderstr. (Bambusoideae-Olyreae), Axonopus aureus P. Beauv., Paspalum polyphyllum Nees ex Trin. (Panicoideae-Paniceae), Chloris elata Nees (Chloridoideae-Cynodonteae), and Eragrostis solida Desv. (Chloridoideae-Eragrostideae) were collected, herborised, and included in the ICN (Herbarium of the Departamento de Botânica da Universidade Federal do Rio Grande do Sul) and HRCB (Rioclarense Herbarium).

Spikelets at different developmental stages were fixed on FAA 50 (Johansen, 1940) and preserved in 70\% ethanol for embryological analyses.

For optical microscopy analyses, individual spikelets and anthers from all species were dehydrated in ethanol series and embedded in Leica ${ }^{\mathrm{TM}}$ historesin, following the manufacturer's protocol. Materials were sectioned with rotative microtome, producing series of transverse and longitudinal sections 1-5 $\mu \mathrm{m}$ thick. These sections were stained with periodic acid Schiff reagent (PAS reaction) and toluidine blue (Feder and O'Brien, 1968), and mounted in synthetic resin. Illustrations were produced through a Leica ${ }^{\mathrm{TM}}$ DFC280 digital camera, coupled to a Leica $^{\mathrm{TM}}$ DMLB photomicroscope, using the program Leica $^{\text {TM }}$ IM50.

For the ultrastructural study of pollen grains, preanthesis stamens of all species were dehydrated in an acetone series (Johansen, 1940), followed by criticalpoint drying with carbon dioxide. The dry material was fixed on metallic supports with $3 \mathrm{M}^{\mathrm{TM}}$ copper adhesive tape. With the aid of stilettos, pollen grains were pulled out of the anthers and then metallised with gold. Pollen grains were observed and photographed in a scanning electronic microscope (Philips ${ }^{\mathrm{TM}}$ SEM 505) and classified according to Punt et al. (1994).

\section{Results}

In the species studied, spikelets of both unisexual and bisexual flowers were observed. In Olyra humilis and Sucrea monophylla (Figure 1) spikelets are unisexual, whereas in Paspalum polyphyllum, Axonopus aureus (Figure 2), Chloris elata, and Eragrostis solida, they are bisexual. Most species presented three stamens arranged in one whorl. Eragrostis solida presents three stamens in young spikelets and two in the mature. Anthers are dorsifixed, bithecal and tetrasporangiate (Figures 1-2, 4-6), with longitudinal dehiscence.

\subsection{Development of the anther wall}

In the species studied, the anther wall development did not differ significantly, and the same pattern was observed in the six species. The anther primordium is formed of meristematic tissue surrounded by an epidermal layer (Figure 3). As the four sporangia develop, anthers become tetralobed (Figures 2, 4).

A monocotyledonous-type development of the anther wall was noted. One individual archeosporic hypodermal cell differentiates into the microsporangium, as follows: the archeosporium cell enlarges, divides periclinally, and forms both the primary wall layer and the primary sporogenous cell (Figure 4).

The primary wall layer then divides and gives origin to the secondary layer (Figure 5). The former layer differentiates into the endothecium, while the secondary layer divides one more time and forms the middle layer 
and the tapetum. They present thin walls and evident nuclei (Figure 6). Starch grains are observed in epidermal and endothecial cells in Olyra humilis (Figure 6) and Sucrea monophylla (Figure 14).

At anther maturity, epidermal cell walls are straight or slightly papillate in Axonopus aureus (Figure 10), convex in Sucrea monophylla and Olyra humilis (Figure 7), concave in Paspalum polyphyllum (Figure 9), and papillate in Chloris elata (Figure 12) and Eragrostis solida (Figures 8,13). Endothecia cells are tangentially elongated and present annular thickenings (Figures 7, 11-13).

In Olyra humilis, the cells in the endothecial layer are larger compared to the other species, occupying approximately two thirds of the anther wall width (Figure 7). The middle layer is ephemeral and disintegrates when the anther matures (Figure 16). Tapetum cells show thin walls, dense cytoplasm, and conspicuous nuclei (Figure 14). The tapetum is secretory (Figures 12, 14, 19), with uninucleate cells in Olyra humilis, Sucrea monophylla, Axonopus aureus, and Paspalum polyphyllum which disintegrate in mature anthers (Figure 16). In Chloridoideae species Chloris elata and Eragrostis solida - the tapetum is uninucleate and occasionally binucleate (Figure 12).

\subsection{Microsporogenesis and microgametogenesis}

In longitudinal sections of young anthers, microsporocytes are usually arranged in four rows of thin-walled cells, showing dense cytoplasm and conspicuous nuclei (Figure 15). In transverse sections of young anthers, 6-8 rows of microsporocytes can be observed in Olyra humilis and Sucrea monophylla (Figures 6, 14), which form a larger number of microspores. In the other species, an average of four rows of microsporocytes are noted.

Microsporocytes divide through meiosis, forming dyads (Figure 16) that are separated by the formation of thin walls, and then isobilateral tetrads (Figure 17), in a process called successive cytokinesis. The tetrad microspores are individualised and have dense cytoplasm and evident nuclei in the central region (Figures 18-19). Microspores enlarge due to vacuolation, while their nuclei migrate toward the periphery and reach the cell wall (Figure 20).

The first mitotic microspore division is unequal and gives origin to two cells: a larger, spherical vegetative cell and a smaller, elongated generative cell with dense cytoplasm and nucleus located at the periphery of the former (Figures 13, 22-23). Subsequently, the generative cell migrates towards the central region, approaching the vegetative cell nucleus (Figure 23); then it undergoes mitosis and originates two sperm cells (Figures 21, 24-25).

In the species studied, pollen grains are dispersed in the tricellular stage, being spheroidal, monosporate, and presenting a surrounding annulus (Figures 26, 27-34). In Sucrea monophylla (Figures 27, 30), the annulus is more conspicuous compared to other species. When pollen grains are observed in transverse section, an exine interruption can be seen internally in the annulus region.
In the central region of the pore, an operculum is seen (Figures 26, 27-34).

Two patterns of exine ornamentation can be distinguished among the species studied: granulose (Figures 29-30) and insular (Figures 31-32). Olyra humilis (Figure 29) and Sucrea monophylla (Bambusoideae) (Figures 27, 30) present the granulose pattern, with individual, compacted granules. The remaining species show the insular pattern, formed of islands of spinules or granules. Axonopus aureus (Figure 31) and Paspalum polyphyllum (Figure 32) (Panicoideae) have densely grouped spinules, whereas in Chloris elata (Figures 28, 34) and Eragrostis solida (Chloridoideae) (Figure 33), they are sparsely grouped.

\section{Discussion}

The number of stamens described for Poaceae varies between one and nine, with the most frequent pattern being three to six stamens (Longhi-Wagner, 2001), which are arranged in one or two whorls (Cocucci and Anton, 1988). Most species present three stamens. In Eragrostis solida, three stamens were seen in young spikelets, and two were observed in the mature ones. Boechat et al. (2001) reported the occurrence of two stamens in Eragrostis solida, probably due to the examination of mature spikelets only. The number of stamens, two or three, is an important taxonomic character in Eragrostis used to separate groups of species in the identification keys (Boechat et al., 2001). Since Eragrostis solida (Chloridoideae) occupies a derived position in phylogenetic studies of the family, the reduction in the number of stamens in mature anthers is probably related to the reduction transition that this floral part underwent.

The monocotyledonous-type anther development observed in the species studied is a common feature in Poaceae (Bhanwra, 1988; Teng et al., 2005) and in most Poales (Sajo et al., 2005), except for Rapateaceae (Venturelli and Bouman, 1988) and Mayacaceae (Venturelli and Bouman, 1986), which present the basic type. The monocotyledonous-type is predominantly found in monocots (Palser, 1975) and may be considered a plesiomorphic character in Poales (Sajo et al., 2005). The endothecia of all species studied show an annular thickening, which is considered one of the most common types found in Poaceae (Manning and Linder, 1990).

Referring to the number of cell layers in the anther wall, Bhandari (1984) reported that, in basal Angiosperms, the anther wall is thick due to the large number of middle layers and occasionally, to a biseriate tapetum. According to the author, in derived Angiosperm families, the anther wall is thin and shows a single series of cells in the middle layer. In the species studied and in Poaceae in general, the anther wall is thin and comprises four layers of cells (Bhanwra, 1988), confirming their derived position in the Angiosperms.

The secretory tapetum described in this study is also considered a constant feature in Poaceae. Although the 

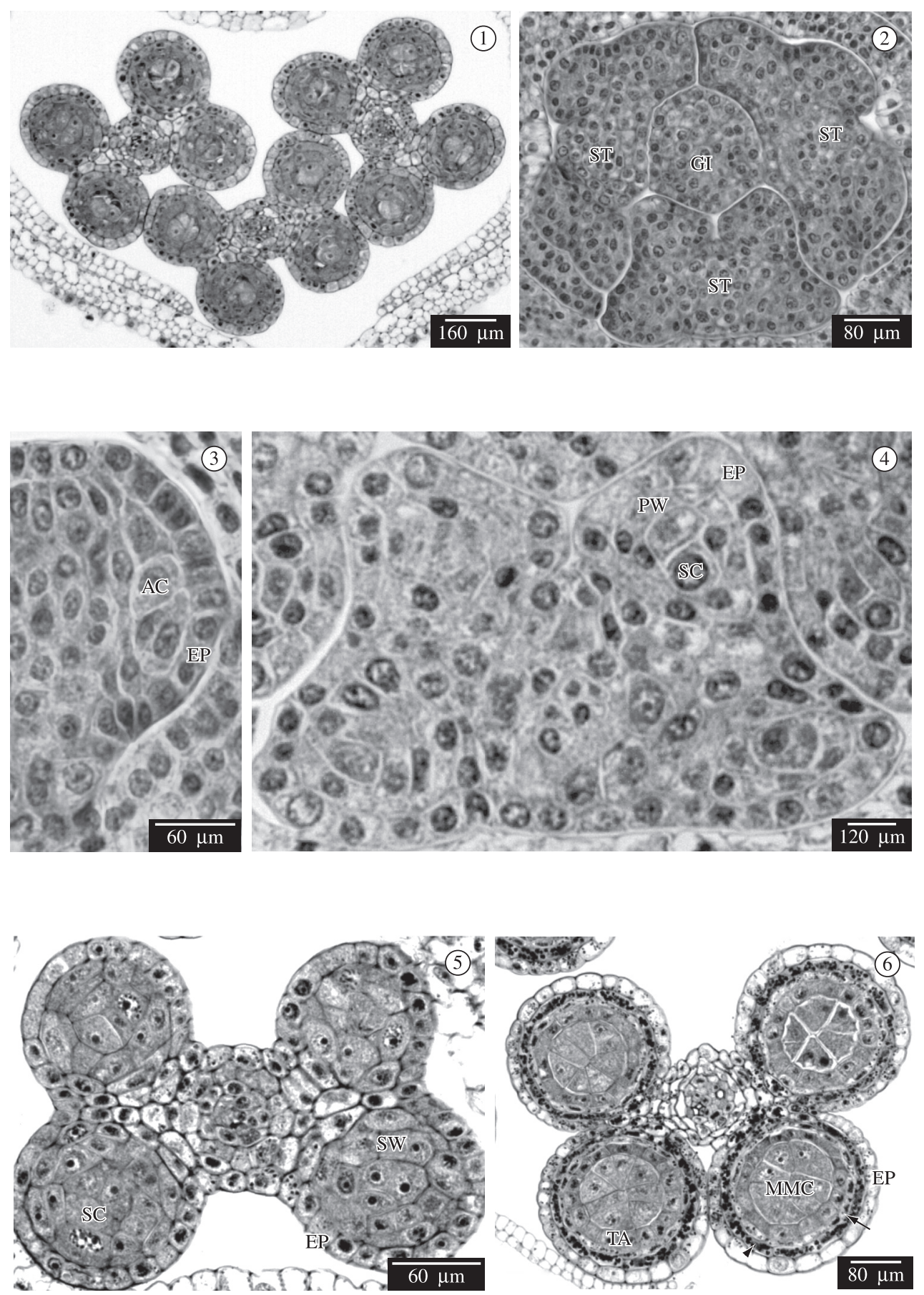

Figures 1-6. Anther wall development in Poaceae. Transverse sections, except 3 longitudinal. 1) Sucrea monophylla male spikelet. 2-4) Axonopus aureus. 5) Sucrea monophylla. 6) Olyra humilis. (AC = archeosporium cell, EP = epidermis, GI = ginoecium, $\mathrm{MMC}=$ microspore mother cell, $\mathrm{PW}=$ primary wall layer, $\mathrm{SC}=$ sporogenous cell, $\mathrm{ST}=$ stamen, $\mathrm{SW}=$ secondary wall layer, TA = tapetum, Arrow = middle layer, Tip of the arrow $=$ endothecium). 

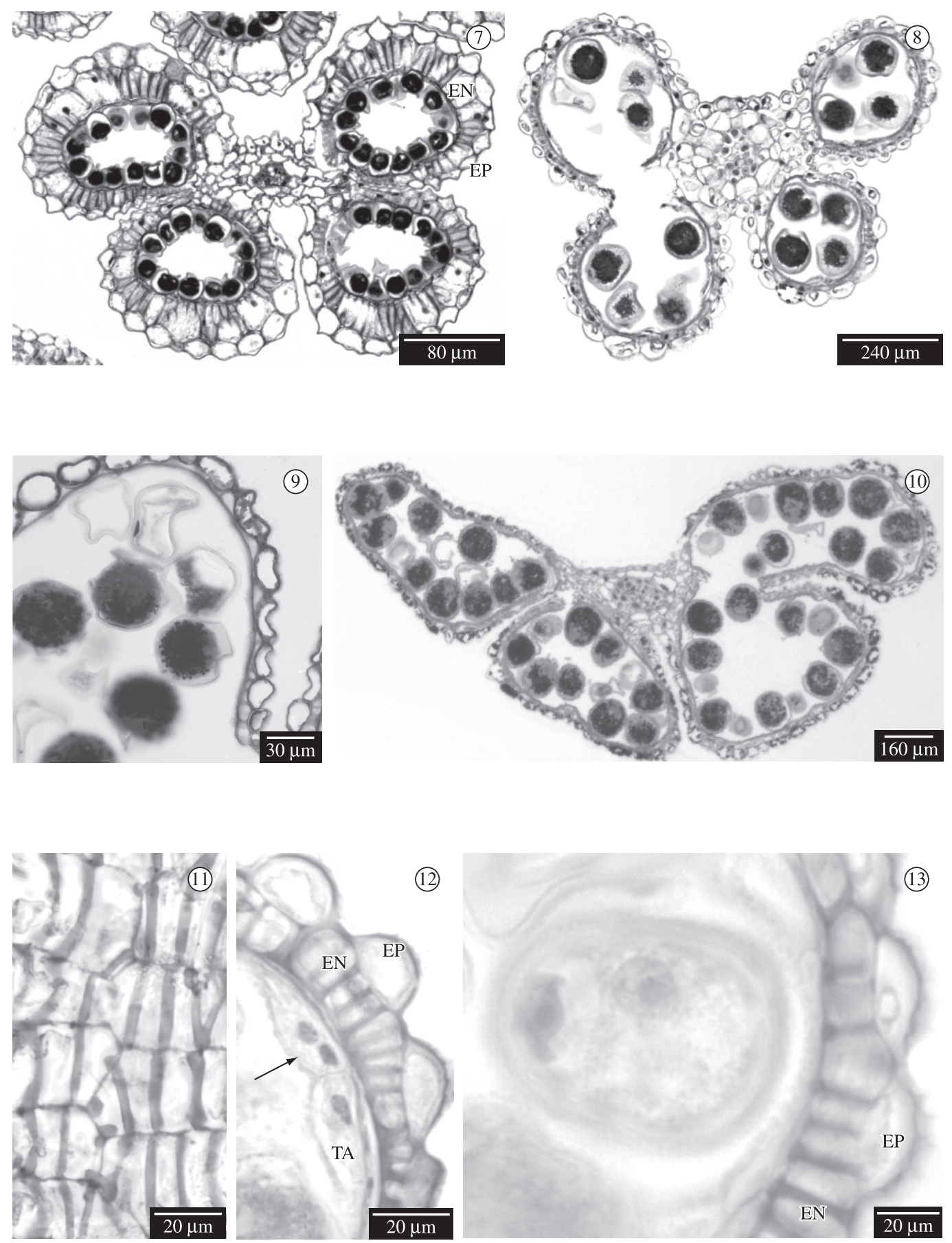

Figures 7-13. Poaceae anther wall development - transverse sections. 7) Olyra humilis. 8) Eragrostis solida. 9) Detail on Paspalum polyphyllum wall. 10) Axonopus aureus. 11) Olyra humilis endothecium. 12) Binucleate tapetum in Chloris elata. 13) Eragrostis solida. $(\mathrm{EN}=$ endothecium, $\mathrm{EP}=$ epidermis, $\mathrm{TA}=$ tapetum, Arrow = binucleate tapetum). 

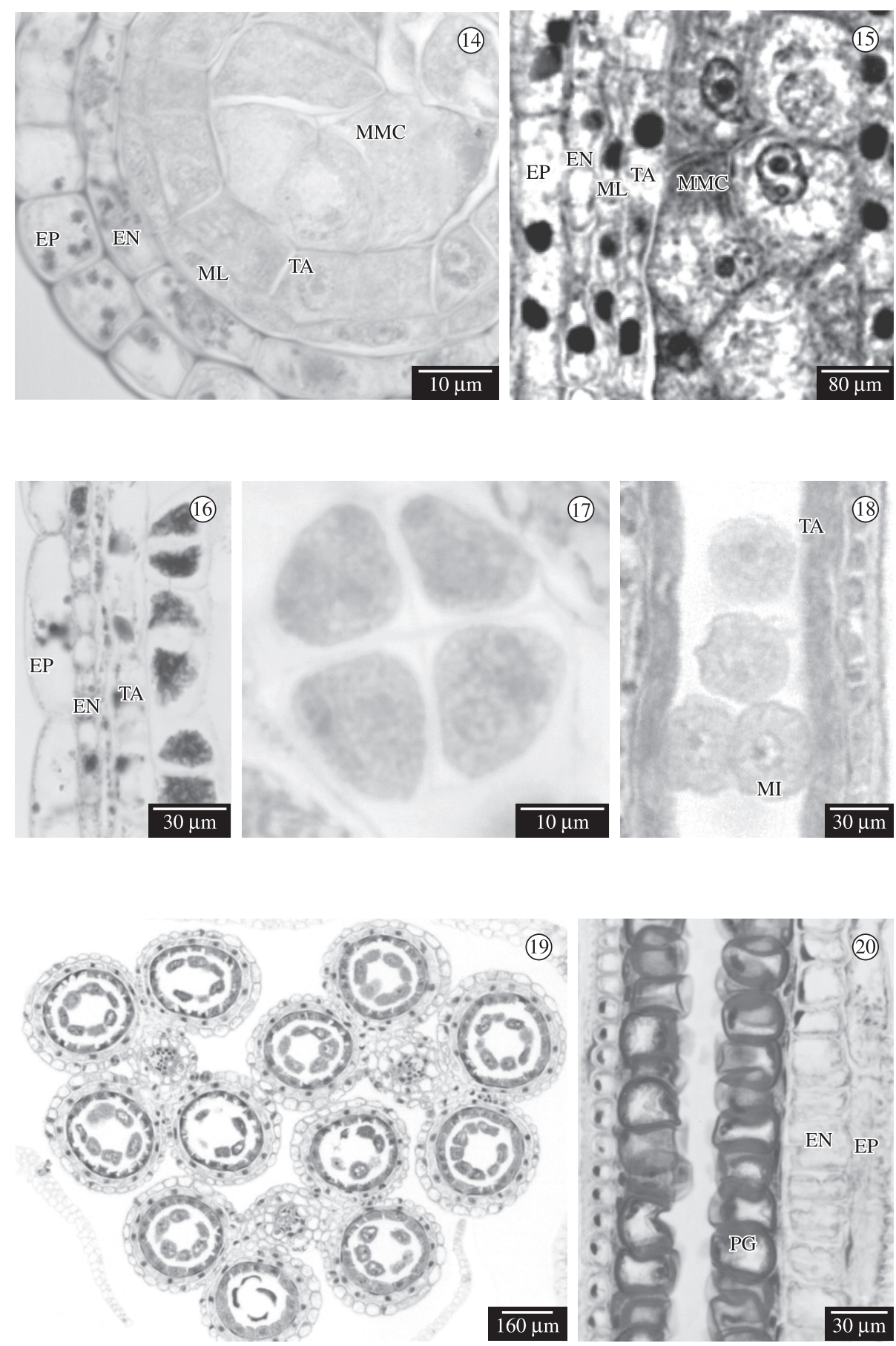

Figures 14-20. Microsporogenesis of Poaceae. 14) Sucrea monophylla microsporangium in transverse section. 15) Longitudinal section of Paspalum polyphyllum microsporangium. 16) Longitudinal section of Axonopus aureus with microspore dyads. 17) Eragrostis solida tetrads. 18) Longitudinal section of Chloris elata, showing individual microspores. 19-20) Transverse and longitudinal sections of Olyra humilis. $(\mathrm{EN}=$ endothecium, $\mathrm{EP}=$ epidermis, $\mathrm{MI}=$ microspores, $\mathrm{ML}=$ middle layer, $\mathrm{MMC}=$ microspore mother cell, $\mathrm{PG}=$ pollen grains, $\mathrm{TA}=$ tapetum $)$. 

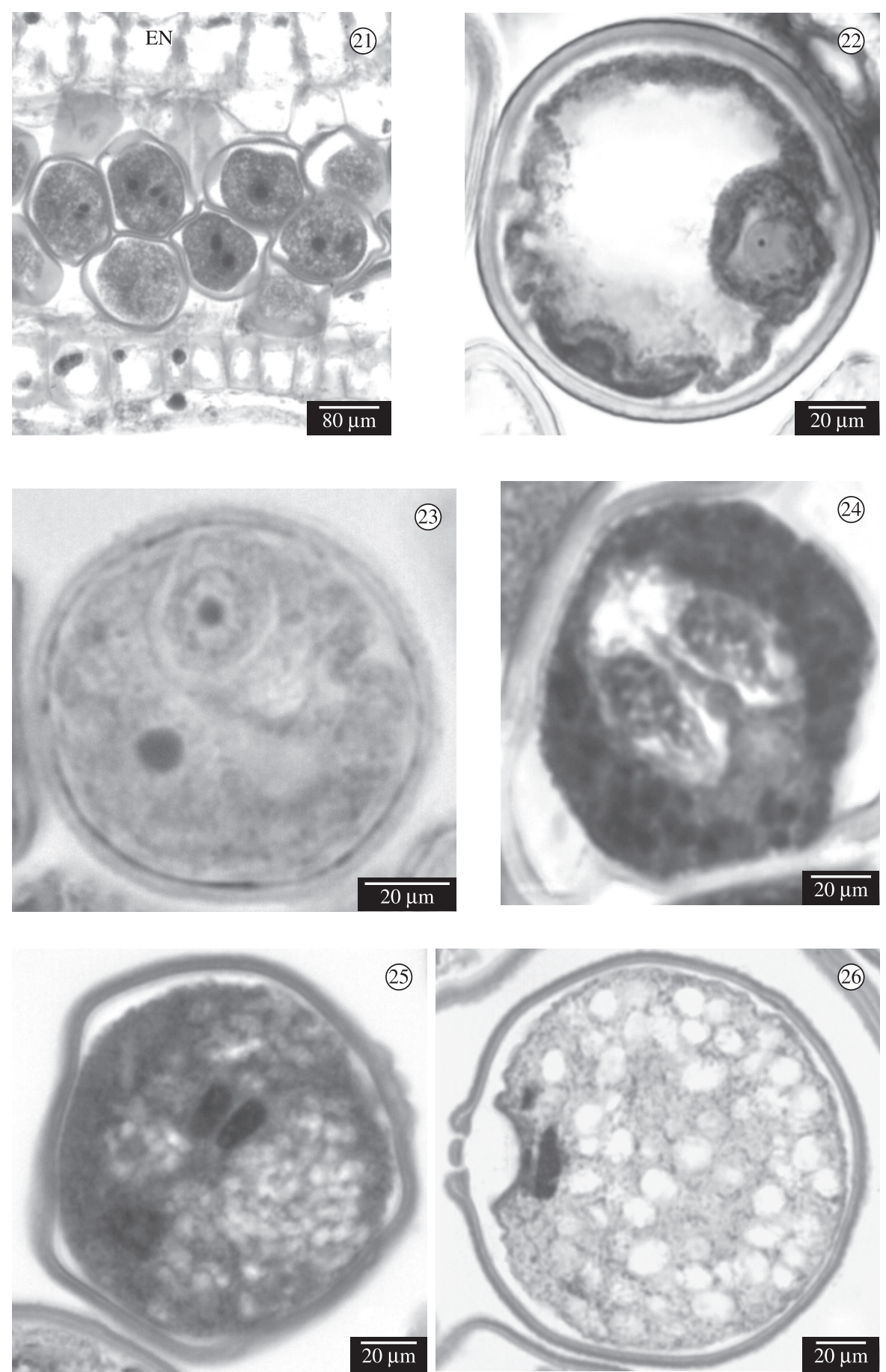

Figures 21-26. Poaceae pollen grains. 21) Longitudinal section of Sucrea monophylla microsporangium. 22) Paspalum polyphyllum. 23) Eragrostis solida. 24) Olyra humilis. 25) Tricellular pollen grain of Paspalum polyphyllum. 26) Detail of the monoporate pollen grain of Sucrea monophylla, showing annulus and operculum. (EN = endothecium). 

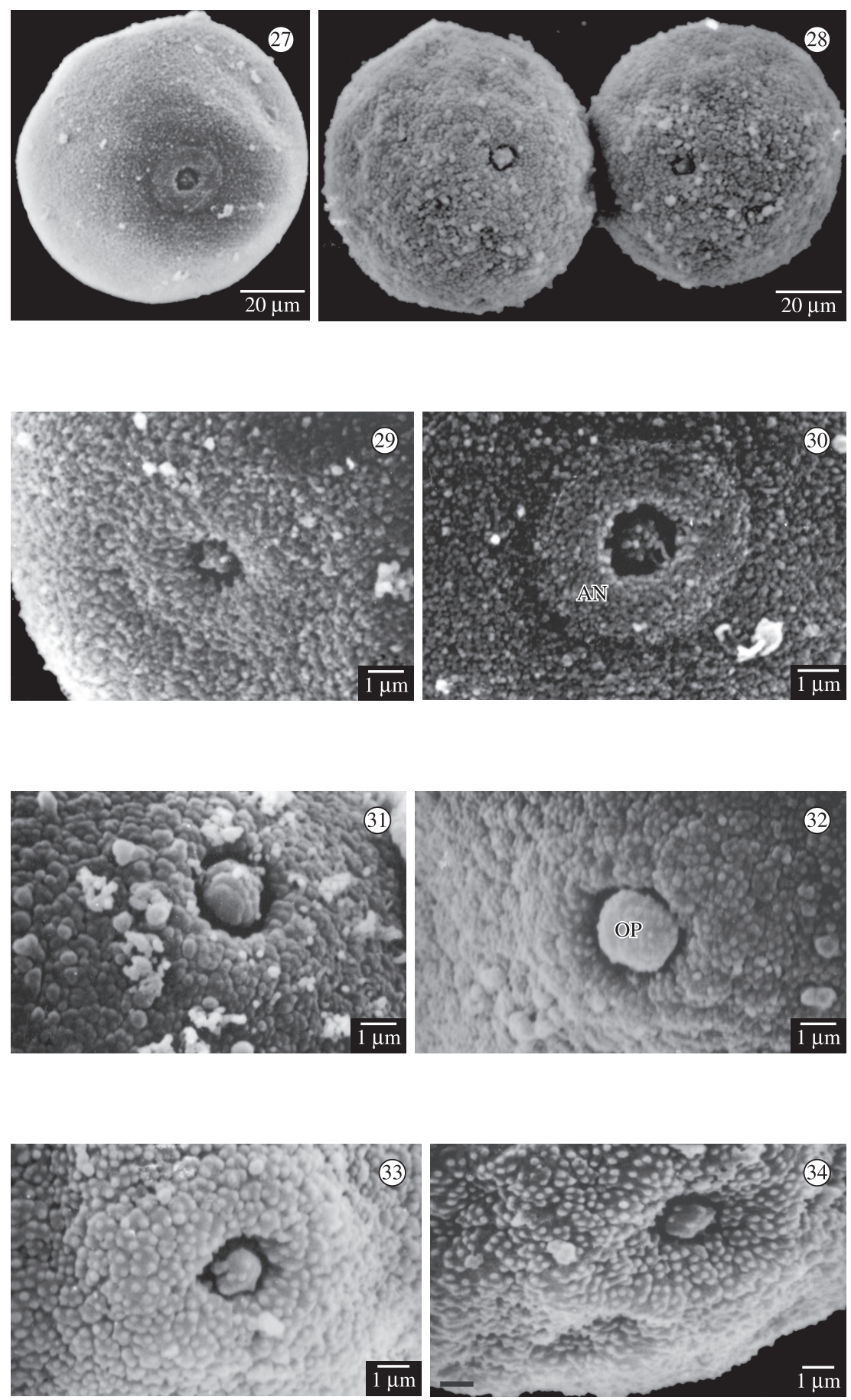

Figures 27-34. Poaceae pollen grains - SEM. 27-28) General aspect of the monosporate pollen grain, showing annulus and operculum, Sucrea monophylla and Chloris elata, respectively. 29-30) Bambusoideae - exine formed of small individual granules. 29) Olyra humilis. 30) Sucrea monophylla. 31-32) Panicoideae - exine with densely arranged spinules. 31) Axonopus aureus. 32) Paspalum polyphyllum. 33-34) Chloridoideae - sparsely insular pattern. 33) Eragrostis solida. 34) Chloris elata. $(\mathrm{AN}=$ annulus, $\mathrm{OP}=$ operculum $)$. 
secretory type is dominant in Poales, a plasmodial type was also reported in the families Sparganiaceae and Typhaceae (Furness and Rudall, 1998). Bromeliaceae, which is a basal taxon (Linder and Rudall, 2005), presents an intermediary type of tapetum that probably derived from an ancestor with a secreting form (Sajo et al., 2005). One or two nuclei are reported for tapetal cells in species of Poaceae, whose occurrence is independent among subfamilies (Bhanwra et al., 1980; Bhanwra, 1988), and thus cannot be considered a constant trait in the group. A binucleate tapetum was observed in Chloris elata and Eragrostis solida (Chloridoideae), but only occasionally. For Dahlgren and Clifford (1982), this character may distinguish taxa among the Monocotyledons in some cases. However, according to Rudall and Furness (1997), the number of nuclei may vary among monocots depending on the developmental stage of the anther.

The more pronounced production of microsporocytes in Olyra humilis and Sucrea monophylla (Bambusoideae) may lead to a greater production of pollen grains, a fact possibly related to their pollination, as these species present unisexual spikelets. It is important to highlight, however, that the populations of these two species grow in the understory, as opposed to the other species, which are characteristic of open grassland formations.

Cruden (1977) studied the pollen-ovule ratio in species of Poaceae with bisexual flowers, including two species of Eragrostis. The ratio observed was low, which the author attributed to the occurrence of self-fecundation. The findings of the present study suggest that selffecundation may be responsible for the formation of a smaller number of microsporocytes in species with bisexual flowers, compared to those with unisexual ones. It may also have led to the loss of one stamen in Eragrostis solida, an important evolutionary step in Poaceae.

In all species studied, the microspore tetrads are isobilateral. This character is frequently found in Poaceae, although T-type, decussate, tetrahedral and linear tetrads have also been described in the family (Bhanwra, 1988). The linear tetrads were similar to those observed in Cephaelis ipecacuanha (Brot.) A. Rich (Souza et al., 2006). Since this character is variable among Poaceae, it should not be considered significant at both familial and infrafamilial levels.

The pollen grains of monocots present sulcate apertures, a predominant condition in the Poales, except in the Thyphaceae and in the graminoid-restiid clade, where the pore replaced the sulcus (Linder and Rudall, 2005), a trait associated with the dispersion of pollen grains (Zavada, 1983). In the graminoid clade presented by Linder and Rudall (2005), diverse structures of pollen apertures were described, with the majority of the representatives showing an annulus similar to the species investigated here. In Restionaceae and Centrolepidaceae, for instance, Linder and Fergunson (1985) reported many types of annulus apertures, but not the intine thickenings commonly seen in Poaceae, which would indicate inde- pendent evolutionary paths. The absence of the annulus in the pollen grain of Poaceae was reported in species of herbaceous bamboos belonging to the genus Pariana (Bambusoideae-Olyreae) (Salgado-Labouriau and Rinaldi, 1990; Salgado-Labouriau et al., 1993; Chissoe et al., 1994; Skvarla et al., 2003). The character 'absence of annulus' or its discrete development, associated with other characters, may be useful in the phylogeny of Poaceae (Skvarla et al. 2003).

The operculum seen in the pollen of the species studied and in the remaining Poaceae might have evolved several times in monocots, as observed by Furness and Rudall (2001) in species of dry, perennial and seasonal habitats. The authors stated that many Poales evolved probably as a result of environmental selection pressures. In Poales, species showing reduced flowers and adaptations to wind pollination have pollen grains dispersed at the tricellular stage (Kapil and Bhatnagar, 1991). Although the investigated species originated from different habitats (understory and open grassland formations), the same constant pattern seen in Poaceae was also observed here.

The exine ornamentation in pollen grains distinguishes the subfamilies studied. Differences in exine patterns were also seen in 18 species of four different groups in the family (Watson and Bell, 1975), as well as in Oryza species (Poaceae-Ehrarthoideae) (Chaturvedi et al., 1998). In another study, Liu et al. (2004) analysed the ornamentation pattern of the exine in pollen grains of Chloridoideae species, describing different patterns: sparsely granulose, densely granulose, rugulate-granulose, grouped granulose, spinulose, verrucose, sparsely insular, compactly insular, brevicerebro-ornate. The authors proposed an evolutionary trend in which the species of ancestral subtribes showing pollen with granulose exine would have given origin to the derived members with the insular pattern, through the gathering of individual granules. Although this hypothesis is suitable for our observations, it cannot be said that the granules seen in the Bambusoideae are ancestrals of the spinule islands observed in the Chloridoideae, since all the patterns we verified were previously described in the subfamily (Liu et al., 2004).

For the species of subfamilies investigated in this study, microsporangium, microsporogenesis and microgametophyte features are constant and characteristic of Poaceae. The exine deposition pattern in pollen grains is a distinguishing trait and may be important at the infrafamilial level.

Acknowledgements - The authors wish to thank CNPq for the PhD scholarship (Proc. $\mathrm{n}^{\circ}$ 140022/2004-0) and CNPq (Proc. $\mathrm{n}^{\circ}$ 471809/2004-7) and FAPESP (Proc. $\mathrm{n}^{\circ}$ 2005/02141-4) for financial grants.

\section{References}

ANGIOSPERM PHYLOGENY GROUP (APG II), 2003. An update of the Angiosperm Phylogeny Group classification for the 
order and families of flowering plants: APG II. Botanical Journal of the Linnean Society, vol. 141, no. 4, p. 399-436.

BHANDARI, NN., 1984. The microsporangium. In: JOHRI, BM. (Ed.). Embryology of Angiosperms. Berlin: Springer. p. 53-121.

BHANWRA, RK., 1988. Embryology in relation to systematics of Gramineae. Annals of Botany, vol. 62, no. 2, p. 215-233.

BHANWRA, RK., KUMAR, S. and CHODA, SP., 1980. Microsporogenesis and male gametophyte in three species of Setaria (Poaceae). Current Science, vol. 49, no. 13, p. 524.

BJÖRNSTAD, IN., 1970. Comparative embryology of Asparagoideae - Polygonateae, Liliaceae. Nytt Magasin for Botanikk, vol. 17, no. 1, p. 169-207.

BOECHAT, SC., GUGLIERI, A. and LONGHI-WAGNER, HM., 2001. Tribo Eragrostideae. In: WANDERLEY, MGL., SHEPHERD, GJ., and GIULIETTI, AM. (Eds.). Flora Fanerogâmica do Estado de São Paulo, vol.1 Poaceae. São Paulo: Fapesp; HUCITEC. p. 61-84.

CHATURVEDI, M., DATTA, K. and NAIR, PKK., 1998. Pollen morphology of Oryza (Poaceae). Grana, vol. 37, no. 1, p. 79-86.

CHISSOE, WF., VEZEY, EL. and SKVARLA, JJ., 1994. Mounting pollen on a thermoplastic adhesive for scanning electron microscopy. Transactions of the American Microscopical Society, vol. 113 , no. 1 , p. $72-79$.

COCUCCI, AE. and ANTON, AM., 1988. The grass flower: suggestions on its origin and evolution. Flora, vol. 181, no. 5-6, p. 353-362.

CRUDEN, RW., 1977. Pollen-ovule ratios: a conservative indicator of breeding systems in flowering plants. Evolution, vol. 31, no. 1, p. 32-46.

DAHLGREN, RMT. and CLIFFORD, HT., 1982. The monocotyledons - a comparative study. London: Academic Press. $378 \mathrm{p}$.

FEDER, N. and O`BRIEN, TP., 1968. Plant microtechnique: some principles and new methods. American Journal of Botany, vol. 55, no. 1, p. 123-142.

FURNESS, CA. and RUDALL, PJ., 1998. The tapetum and systematics in monocotyledons. The Botanical Review, vol. 64, no. 3, p. 201-239.

,2001. Pollen and anther characters in monocot systematics. Grana, vol. 40, no. 1, p. 17-25.

Grass Phylogeny Working Group - GPWG, 2001. Phylogeny and subfamilial classification of grasses (Poaceae). Annals of the Missouri Botanical Gardern, vol. 88, no. 3, p. 373-457.

JOHANSEN, DA., 1940. Plant microtechnique. New York: McGraw-Hill Book. 523 p.

KAPIL, RN. and BHATNAGAR, AK., 1991. Embryological evidence in angiosperm classification and phylogeny. Botanische Jahrbücher für Systematik, vol. 113, no. 2-3, p. 309-338.

LINDER, HP. and FERGUSON, IK., 1985. On the pollen morphology of Restionales and Poales. Grana, vol. 24, no. 1, p. 65-76.

LINDER, HP. and RUDALL, PJ., 2005. Evolutionary history of Poales. Annual Review of Ecology, Evolution, and Systematics, vol. 36, no. 1, p. 107-124.

LIU, Q., ZHAO, NX. and HAO, G., 2004. Pollen morphology of the Chloridoideae (Gramineae). Grana, vol. 43, no. 1, p. 1-10.

LONGHI-WAGNER, HM., 2001. Poaceae. In: WANDERLEY, MGL., SHEPHERD, GJ. and GIULIETTI, AM. (Eds.). Flora
Fanerogâmica do Estado de São Paulo. vol.1: Poaceae. São Paulo: Fapesp; HUCITEC. p. 1.

MANNING, JC. and LINDER, HP., 1990. Cladistic analysis of patterns of endothecial thickenings in the Poales/Restionales. American Journal of Botany, vol. 77, no. 1, p. 196-210.

PALSER, BF., 1975. The bases of Angiosperm phylogeny: embryology. Annals of the Missouri Botanical Garden, vol. 62, no. 3, p. 621-646.

PUNT, W., BLACKMORE, S., NILSSON, S. and LE THOMAS, A., 1994. Glossary of pollen and spore terminology. Available from:http://www.bio.uu.nl/ palaeo/glossary/glos-int.htm. Access in: October 30, 2007.

RUDALL, PJ. and FURNESS, CA., 1997. Systematics of Acorus: ovule and anther. International Journal of Plant Sciences, vol. 158, no. 5 , p. $640-651$

RUDALL, PJ., FURNESS, CA., CHASE, MW. and FAY, MF., 1997. Microsporogenesis and pollen sulcus type in Asparagales (Lilianae). Canadian Journal of Botany, vol. 75, no. 3, p. 408-430.

SAARELA, JM., RAI, HS., DOYLE, JA., ENDRESS, PK., MATHEWS, S., MARCHANT, AD., BRIGGS, BG. and GRAHAM, SWI., 2007. Hydatellaceae identified as a new branch near the base of the angiosperm phylogenetic tree. Nature, vol. 446, no. 7133 , p. 312-315

SAJO, MG., FURNESS, CA., PRYCHID, CJ. and RUDALL, PJ., 2005. Microsporogenesis and anther development in Bromeliaceae. Grana, vol. 44, no. 2, p. 65-74.

SALGADO-LABOURIAU, ML. and RINALDI, M., 1990. Palynology of the Gramineae of the Venezuelan mountains. Grana, vol. 29, no. 2, p. 119-128.

SALGADO-LABOURIAU, ML., NILSSON, S. and RINALDI, M., 1993. Exine sculpture in Pariana pollen (Gramineae). Grana, vol. 32, no. 4-5, p. 243-249.

SÁNCHEZ-KEN, JG., CLARK, LG., KELLOGG, EA. and KAY, EE., 2007. Reinstatement and emendation of subfamily Micrairoideae (Poaceae). Systematic Botany, vol. 32, no. 1, p. 71-80.

SKVARLA, JJ., ROWLEY, JR., HOLLOWELL, VC. and CHISSOE, WF., 2003. Annulus-pore relationship in Gramineae (Poaceae) pollen: the pore margin of Pariana. American Journal of Botany, vol. 90, no. 6, p. 924-930.

SOUZA, MM., MARTINS, ER., PEREIRA, TNS. and OLIVEIRA, LO., 2006. Reproductive studies in epecac (Cephaelis ipecacuanha (Brot.) A. Rich; Rubiaceae): meiotic behavior and pollen viability. Revista Brasileira de Biologia = Brazilian Journal of Biology, vol. 66, no. 1a, p. 151-159.

TENG, N., HUANG, Z., XIJIN, M., JIN, B., HU, Y. and LIN, J., 2005. Microsporogenesis and pollen development in Leymus chinensis with emphasis on dynamic changes in callose deposition. Flora, vol. 200, no. 3, p. 256-263.

VENTURELLI, M. and BOUMAN, F., 1986. Embryology and seed development in Mayaca fluviatilis (Mayacaceae). Acta Botanica Neerlandica, vol. 35, n. 4, p. 497-516.

1988. Development of ovule and seed Rapateaceae. Botanical Journal of the Linnean Society, vol. 97, no. 3, p. 267-294.

WATSON, L. and BELL, EM., 1975. A surface-structural survey of some taxonomically diverse grass pollens. Australian Journal of Botany, vol. 23, no. 6, p. 981-990.

ZAVADA, MS., 1983. Comparative morphology of monocot pollen and evolutionary trends of apertures and wall structures. The Botanical Review, vol. 49, no. 4, p. 331-379. 